Philosophie ANTIQUE

\section{Philosophie antique}

Problèmes, Renaissances, Usages

14 | 2014

Le devoir

\title{
Reading Descartes as a Stoic
}

Appropriate Action, Virtue, and the Passions

\section{Donald Rutherford}

\section{(2) OpenEdition}

\section{Journals}

Electronic version

URL: https://journals.openedition.org/philosant/777

DOI: $10.4000 /$ philosant.777

ISSN: 2648-2789

\section{Publisher}

Éditions Vrin

\section{Printed version}

Date of publication: 1 November 2014

Number of pages: 129-155

ISBN: 978-2-7574-0855-1

ISSN: 1634-4561

\section{Electronic reference}

Donald Rutherford, "Reading Descartes as a Stoic", Philosophie antique [Online], 14 | 2014, Online since 01 November 2018, connection on 05 December 2022. URL: http://journals.openedition.org/philosant/ 777 ; DOI: https://doi.org/10.4000/philosant.777

\section{(c) (i) (3)}

Creative Commons - Attribution-NonCommercial-NoDerivatives 4.0 International - CC BY-NC-ND 4.0 https://creativecommons.org/licenses/by-nc-nd/4.0/ 
READING DESCARTES AS A STOIC:

Appropriate Action, Virtue, and the Passions

Donald RUTHERFORD

University of California, San Diego

RÉSUMÉ. Bien que Descartes n'emploie que rarement les mots officium ou « devoir », sa morale confère une place centrale à la notion d'action appropriée, dans un sens qui rappelle le kathekon des stoïciens. Cette notion enveloppe les devoirs de l'être humain envers Dieu et envers les autres êtres humains, ainsi que les actions qui trouvent leur justification dans le fait qu'elles favorisent la conservation et la santé du corps. Tout en relevant ces parallèles, je montre également que Descartes, dans son analyse de la vertu et des passions, s'écarte des doctrines stoïciennes; divergence que j'explique en partie par l'acceptation de la tripartition des biens (bien moral, biens du corps, biens extérieurs) que rejettent les stoïciens.

SUMMARY. Although Descartes does not use the terms officium or devoir with any frequency, his ethics gives a central place to the notion of appropriate action in a sense reminiscent of the Stoics's kathekon. Within this category are included a human being's duties to God and to other human beings, and actions whose aptness stems from their promotion of the survival and health of the body. While noting these parallels, I also show how Descartes's accounts of virtue and the passions diverge from Stoic views, ascribing these differences in part to his acceptance of the threefold division of goods (moral, bodily, external) rejected by the Stoics. 



\section{Introduction}

Stoicism has served as a reference point for many interpretations of Descartes's moral philosophy. Descartes himself provides support for such an association in letters to Princess Elisabeth and in works from the Discours de la méthode to Les Passions de l'âme. Yet caution must be exercised in extrapolating from this evidence. In contrast to Neostoic writers such as Justus Lipsius and Guillaume Du Vair, Descartes claims no allegiance to Stoicism or to any other sect of the ancients, whose methods he finds inadequate. Moreover, there are substantial doctrinal differences between Descartes and the Stoics. Given this, the attempt to label him a "Stoic" in any strict sense of the word must be rejected. ${ }^{1}$

Despite this conclusion, I believe, there remains a case for reading Descartes as a Stoic, or for adopting Stoicism as a framework within which to interpret his moral philosophy. Taking up this perspective requires assuming that Stoicism is relevant to the comprehension of Descartes's ethics, but it does not commit one to the thesis that Descartes is a Stoic, or that Stoicism is unique in the light it casts on his views. As I intend my title, it signifies the strategy of elucidating Descartes's ethical theory by probing the parallels between it and Stoic ethics. Irrespective of Descartes's intentions or his knowledge of Stoicism, his ethical thought follows channels dug by the Stoics. By making these traces explicit, we can deepen our understanding of his moral philosophy and of the extent to which ancient patterns of ethical thought persist in the early modern period. ${ }^{2}$ In what follows, I pursue this strategy with special attention to the Stoic concept of

1. Cf. Olivo 1999, who surveys the earlier literature on the topic. Among other recent studies that explore Stoic elements in Descartes's ethics, see Marshall 1998; Mehl 1999; Shapiro 2011.

2. In speaking of Descartes's "moral philosophy" or "ethics", I refer to the views expressed in his late letters and in the Passions, as against the "morale par provision" of the Discours or "la plus haute et la plus parfaite Morale" projected in the preface to the French translation of the Principia. On the relation among these different versions of his moral philosophy, see Rodis-Lewis 1957; Kambouchner 2008. 
kathekon, or officium, expressed variously in French as "convenable" and "devoir", and in English as "proper function", "appropriate action", and "duty" (to mention only a few of the possibilities). The range of translations available for the terms laid down in Greek (by Zeno) and Latin (by Cicero) is indicative of the broad semantic field that the Stoics associate with them. ${ }^{3}$ Most fundamentally, kathekon designates a form of activity that is appropriate to the constitution of a particular kind of life. When a living being acts in this way, it acts in accordance with nature (kata physin), which is how it properly should act. In this widest sense, kathekon (or "appropriate action", as I will designate it ${ }^{4}$ ), extends to plants and animals, insofar as they act to preserve their lives and constitutions. ${ }^{5}$ The same basic sense of appropriate action applies to human beings as well, but in this case, the primary import of kathekon, or officium, is transferred to actions to which we are led by reason as determined by the "ruling principle" (hegemonikon) of the soul. Thus, "proper functions [kathekonta] are ones which reason dictates our doing, such as honouring parents, brothers and country, spending time with friends; contrary to proper function are ones which reason dictates our not doing, such as neglecting parents, not caring about brothers, not treating friends sympathetically, not acting patriotically, etc." ${ }^{\prime 6}$

Taken in this narrower sense, officia (to use Cicero's term) fall under the category of devoir or duty. The claim such officia have on us is a consequence of reason's representation of such actions as appropriate to our existence as human beings. Epictetus explains this point by noting that

Appropriate actions are in general measured by relationships. He is a father: that entails taking care of him, yielding to him in everything, putting up with him when he abuses you or strikes you. [...] In this way, then, you will discover the appropriate actions to expect from a neighbor, from a citizen, from a general, if you are in the habit of looking at relationships. ${ }^{7}$

The relationships in which we stand to family members, friends, fellow citizens, and humanity as a whole are taken by the Stoics to define us as

3. For Zeno's introduction of kathekon, see Diogenes Laertius (hereafter: DL), VII, $107-$ 8; for Cicero's rendering of it as officium, De finibus, III, 20.

4. Long \& Sedley 1987, vol. 1, p. 365, use "proper function", which I retain in quoting from them. Texts drawn from this edition are cited as LS, followed by the chapter number and entry letter.

5. DL VII, 85-6 (LS 57A), and 107: "an appropriate [action], they say, is that which, when done, admits of a reasonable defence [eulogon apologismon], such as what is consistent in life, and this extends also to plants and animals" (trans. Inwood and Gerson 1997, p. 196). Cf. Stobaeus, II, 85 (LS 59B).

6. DL VII, 108 (LS 59E). (I have modified LS's "does not dictate our doing" to reflect the intended sense of reason's ruling against the types of actions mentioned.)

7. Epictetus, Encheiridion, c. 30 (trans. White 1983, p. 20-21). 
human. Affective bonds tie us to those to whom we are related in these ways, but these bonds alone do not generate officia. Officia depend on reason's representation of the appropriateness of actions associated with these relations: each of the "titles" under which we stand, "when rationally considered, always suggests the actions appropriate to it."

Officia, then, are the source of normative demands that are registered in any human being whose ruling principle, or practical reason, operates as it should. To the extent that one fails to recognize and to act on these claims of duty, one's powers of cognition and assent fail in the execution of their proper functions. The Stoics, however, draw a sharp distinction between mere responsiveness to normative demands, evidenced in the doing of appropriate actions, and virtuous action, the actions performed by a person who meets the highest standard of moral excellence, identified with the supreme good and happiness (eudaimonia). As Cicero articulates the distinction, it is between a perfectum officium, which is a "right" action (in Greek, katorthoma), and a medium officium (kathekon), which is an action for which a reasonable account can be given as to why it has been done ("quod cur factum sit, ratio probabilis reddi possit").? Appropriate action in the latter sense is common to the virtuous, or wise, and to those who fail to meet the standard of virtue; however, only the virtuous perform appropriate actions in a way that qualifies as right.

Precisely what the virtuous must do or be in order that their actions have this characteristic remains contested. In the Stoic sources, we can identify at least three features that distinguish the actions of the virtuous person from those of the non-virtuous: (i) whereas the ordinary person performs appropriate actions because he values the outcomes of the actions (e.g. the benefit that accrues to a friend), the virtuous person performs the same actions only because they evidence "consistency" (homologia, convenientia), or are in agreement with nature; ${ }^{10}$ (ii) whereas the ordinary person knows that officia are to be done, the virtuous persons know exactly when, and in what circumstances, any particular appropriate action is to be performed; ${ }^{11}$ (iii) whereas the ordinary person's actions are based on belief or opinion, the virtuous person's actions are based on knowledge (of the sort expressed in (i) and (ii)), giving his actions "the additional properties of firmness and tenor and their own particular fixity". ${ }^{12}$ Going into greater

8. Epictetus, Discourses, II, 10, 12 (LS 59Q).

9. Cicero, De officiis, I, 8. Cf. De finibus, III, 58.

10. Cicero, De finibus, III, 21; hence, the Stoics's formula for the final end, rendered by Cicero as "congruenter naturae convenienterque vivere" (ibid. 26). Cf. Seneca, Ep. 74, 30: "Virtus enim convenientia constat".

11. Cicero, De finibus, III, 59-60.

12. Stobaeus, 5.906, 18 - 907, 5 (LS 59I). 
detail about the relationship among these features of virtuous action would take us beyond the scope of this essay. Here it is enough to note the categorical distinction for the Stoics between, on the one hand, virtuous or right action, and on the other, dutiful action that falls short of virtue, because it lacks the epistemic and volitional credentials of virtuous action. In the case of the person who is not a sage, appropriate action is supported by opinion rather than knowledge, and hence the will of the agent performing the action lacks the "firmness" and "fixity" that mark the will of a virtuous agent.

Having established this background for understanding the Stoics's conception of appropriate action, we are in a position to consider how Descartes's philosophy relates to it. Although Descartes does not use the terms officium or devoir with any frequency, his ethics can be shown to assign an important place to the notion of appropriate action in a sense that approximates the Stoics's conception of it. At the same time, Descartes defends a different account of virtue than the Stoics, identifying it with a "firm and constant" will to do whatever reason judges best. After laying out the case for this interpretation in sections 2 and 3, I turn in section 4 to a second, related manifestation of kathekon in Descartes's theory of the passions. Although Descartes's explanation of the nature of the passions diverges from that of the Stoics, he agrees with them that the passions involve impulses toward, or away from, objects that are represented as appropriate ("convenable") or harmful ("nuisible") to us. As such, the passions offer prima facie reasons for the will to affirm the course of action they incline us toward. Once again distancing himself from the Stoics on virtue, Descartes rejects their characterization of the wise person as apathe. Instead, he identifies virtue with a firm will to act in accord with the greatest reason, or, for the sake of the greatest good, whether that good is represented as belonging to the soul or to the living body with which it is united.

\section{Descartes's Divergence From the Stoics}

Descartes's most extensive engagement with Stoic thought appears in a series of letters exchanged with Princess Elisabeth of Bohemia in 1645. In the course of these letters, responding to the argument of Seneca's De vita beata, Descartes makes an intriguing attempt to recast the relations among the core concepts of eudaimonist ethics: happiness ("la béatitude"), defined as "un parfait contentement d'esprit \& une satisfaction interieure" (AT IV, $264)^{13}$; the supreme good ("le souverain bien"), identified with virtue; and

13. Descartes's writings are cited according to the revised Adam-Tannery edition (AT = Adam-Tannery 1996), by volume and page number. In quoting from this edition I have preserved the orthography of the printed text. Latin writings are given in English translation 
the final end ("la derniere fin"), which he claims can be understood to be either of these (AT IV, 275). I have discussed this aspect of Descartes's thought elsewhere. ${ }^{14}$ Here, I focus on his account of virtue as the supreme good for a human being and its relation to the notion of appropriate action.

Descartes's fullest explanation of the concept of virtue occurs in a letter to Queen Christina of Sweden, written approximately two years after his exchange with Elisabeth. Addressing Christina's request that he elaborate on his view of "le Souverain Bien, consideré au sens que les Philosophes anciens en ont parle", Descartes writes:

[L]e souverain bien [...] d'un chacun en particulier [...] ne consiste qu'en une ferme volonté de bien faire, \& au contentement qu'elle produit. Dont la raison est que je ne remarque aucun autre bien qui me semble si grand, ny qui soit entierement au pouvoir d'un chacun. Car, pour les biens du corps \& de la fortune, ils ne dependent point absolument de nous; \& ceux de l'ame se raportent tous à deux chefs, qui sont, l'un de connoistre, \& l'autre de vouloir ce qui est bon; mais la connoissance est souvent au delà de nos forces; c'est pourquoy il ne reste que nostre volonté, dont nous puissions absolument disposer. Et je ne voy point qu'il soit possible d'en disposer mieux, que si l'on a tousjours une ferme \& constante resolution de faire exactement toutes les choses que l'on jugera estre les meilleures, \& d'employer toutes les forces de son esprit à les bien connoistre. C'est en cela seul que consistent toutes les vertus; c'est cela seul qui, à proprement parler, merite de la loüange $\&$ de la gloire; enfin c'est de cela seul que resulte tousjours le plus grand \& le plus solide contentement de la vie. Ainsi j'estime que c'est en cela que consiste le souverain bien.(AT V, 82-3) ${ }^{15}$

There are clear echoes of Stoic views in Descartes's account of virtue. Virtue is explained in terms of the "firmness" and "constancy" of one's will to act rightly. Virtue is our supreme good, because it is the perfection of that which is entirely within each person's power and most properly his own, namely, the will. As Descartes writes in the same letter, "le libre arbitre est de soy la chose la plus noble qui puisse estre en nous [....] [S]on bon usage est le plus grand de tous nos biens, il est aussi celuy qui est le plus proprement nostre \& qui nous importe le plus" (AT V, 85). For this reason, virtue is both necessary and sufficient for happiness: without virtue, no one can enjoy the perfect contentment of mind that Descartes identifies with "la

from Cottingham et al. 1984, vol. 2 (abbreviated CSM II, followed by page number) or 1991 (abbreviated CSMK, followed by page number).

14. Rutherford 2004.

15. Compare his comments to Elisabeth at AT IV, 265, 276, 305. 
béatitude"; with virtue, we can be content even in the absence of other goods, for which we remain dependent on fortune. ${ }^{16}$

In advancing this account of virtue, Descartes also departs in significant ways from the Stoics. There is, first, the broad extension he gives to the term "good", allowing it to range over goods of the soul, goods of the body and goods of fortune. ${ }^{17}$ While this point is not negligible, it is mitigated by his locating virtue in a class by itself as "le souverain bien", which is sufficient for happiness. Another difference is his willingness to use the term "virtue" in a more expansive way than the Stoics. Descartes makes no claim for a sharp distinction between virtue as an ideal realized in only the most extraordinary souls and the general condition of vice. Instead, like many of his contemporaries, he treats virtue as a perfection that exists on a continuum. One can be more or less virtuous, while approaching the ideal of perfect virtue. A third difference, and the one on which I will focus, concerns their respective conceptions of the relation between the firmness and constancy of a virtuous will, on the one hand, and its being determined by reason, or knowledge of the good, on the other.

Invocations of the firmness and constancy of the virtuous person's mind are ubiquitous in Stoic and Neostoic accounts of virtue. ${ }^{18}$ Common to these accounts is the idea that the constancy (or consistency) and strength of mind of the virtuous person are consequences of the rightness of his reason. Only by knowing what is "honnête et convenable" (to use Du Vair's expression) does one's mind acquire the qualities expressive of virtue. By contrast, any possibility of mistaking false goods for true goods, as happens if one's judgments are based on opinion rather than knowledge, undermines the firmness and constancy of one's will. Thus, for the Stoics, virtue consists in a state of knowledge that infallibly disposes one to assent to things in accordance with a true measure of their value. ${ }^{19}$

16. AT IV, 266-7, 277.

17. Descartes applies the term "good" both to what the Stoics classify as good and to what they claim merely has "value", that is, "whatever is according to nature or brings about that which is" (Cicero, De finibus, III, 20). Thus, he includes within the class of goods what the Stoics distinguish as "advantages" (commoda), which are to be preferred or promoted but not chosen for their contribution to happiness (cf. Cicero, ibid. 69).

18. See, e.g., Seneca, Ep. 92, 3 (LS 63F); J. Lipsius, De constantia libri duo, qui alloquium praecipue continent in publicis malis, Leiden, Plantin, $3^{\text {rd }}$ ed. 1586, p. 10, 18; G. Du Vair, Les Oeuvres du Sr. Du Vair, Rouen, Vereul, 1617, p.732. On the background to this idea, see Lagrée 2004.

19. As Plutarch writes of the early Stoics, "All these men agree in taking virtue to be a certain character and power of the soul's commanding-faculty [hegemonikon], engendered by reason, or rather, a character which is itself consistent, firm, and unshakeable reason" ( $O n$ Moral Virtue, 441B-C; LS 61B). Cf. Stobaeus, 5.906, 18 - 907, 5 (LS 59I). 
Descartes offers a different explanation of an agent's virtue. In his view, virtue is properly a perfection of the will rather than reason. It consists principally in "une ferme \& constante resolution de faire exactement toutes les choses que l'on jugera estre les meilleures" (AT V, 83) ${ }^{20}$ To this extent, he concedes, the scholastics were right to describe virtue as a disposition, or habit, "car, en effect, on ne manque gueres, faute d'avoir, en theorie, la connoissance de ce qu'on doit faire, mais seulement faute de l'avoir en pratique, c'est a dire faute d'avoir une ferme habitude de la croyre" (AT IV, 296). At the same time, he insists that virtue does not require perfect knowledge. Virtue requires that the will be guided by reason, for without this, "la volonté \& resolution de bien faire nous peut porter a des choses mauvaises, quand nous les croyons bonnes" (AT IV, 267). Nevertheless, a person can exhibit virtue even if, having used his reason as well as he can, he errs in his judgment of how the greatest good can be produced:

[A]insi la vertu ne consiste qu'en la resolution \& la vigueur avec laquelle on se porte à faire les choses qu'on croit estre bonnes, pourvû que cette vigueur ne vienne pas d'opiniastreté, mais de ce qu'on sçait les avoir autant examinées, qu'on en a moralement de pouvoir. Et bien que ce qu'on fait alors puisse estre mauvais, on est assuré neantmoins qu'on fait son devoir; au lieu que, si on execute quelque action de vertu, \& que cependant on pense mal faire, ou bien qu'on neglige de sçavoir ce qui en est, on n'agit pas en homme vertueux. (AT V, 83-4)

According to Descartes, we have done our duty ("son devoir"), all that can be expected of us, if we act after having weighed possible courses of action to the best of our ability ("qu'on en a moralement de pouvoir"). There is no requirement that the action decided on be one that a perfectly informed rational agent would perform in the same circumstances. This does not mean that Descartes countenances moral laxness. If one fails to use one's reason as well as one can in ascertaining the expected goodness of competing courses of action, then one cannot be virtuous. Yet it is consistent with the possession of a virtuous character that one should do everything within one's power to determine the best course of action and still fail to realize the greatest good.

Descartes's insistence that virtue does not require perfect knowledge reflects a substantial disagreement with the Stoics concerning the relation of the human mind and God. Whereas for the Stoics virtue is realized when there is a harmony or agreement between a human mind and the

20. See also his letter to Elisabeth of 4 August 1645: “[...] c'est la fermeté de cete resolution, que je croy devoir estre prise pour la vertu, bien que je ne sçache point que personne l'ait jamais ainsy expliquée; mais on l'a divisée en plusieurs especes, ausquelles on a donné divers noms, a cause des divers objets ausquels elle s'estend". (AT IV, 265) 
divine mind, Descartes denies that we can share directly or fully in God's knowledge of the universe. ${ }^{21}$ The way in which we are most like God, rather, is in our possession of a free will: "il nous rend en quelque façon semblables à Dieu, en nous faisant maistres de nous mesmes, pourvû que nous ne perdions point par lacheté les droits qu'il nous donne". ${ }^{22}$

Although Descartes distinguishes himself in these ways from the Stoics, he preserves important elements of the Stoic account of virtue. He begins by identifying the part of us that is most properly our own with the part in which we are most like God. And he characterizes virtue in terms of the correct use, or proper functioning, of that part. For the Stoics, this is our power of rational assent, where it is assumed that an action is virtuous only if it is grounded in a complete grasp of the truth. For Descartes, virtue is equally a matter of using our power of assent well, but this power is ascribed to a distinct volitional capacity ("le libre arbitre"), which we use correctly if its operation is guided by reason, to the extent we are able to do so. With respect to the notion of virtue itself - the excellence of rational agency - Descartes and the Stoics defend similar positions. Their differences stem from their respective conceptions of the powers of a rational soul and the relation of those powers to the divine mind.

\section{Deciding How to Act: The Role of Officia}

For Descartes, the will is the source of both theoretical and practical judgments; it is the power to affirm or deny something as true, and to pursue or avoid something as good (AT VII, 57). Although he identifies the will (voluntas) with a freedom of choice (libertas arbitrii), he does not conceive of the latter as a "liberty of indifference". When we exercise our power of willing, "we do not feel that we are determined by any external force"; nevertheless the movements of the will are responses to internal representations of things. The proper function of the will is to assent to things only

21. On the agreement of divine and human reason, see DL VII, 88; Seneca, Ep. 124, 14; Epictetus, Discourses, II, 19, 26-27. Descartes's reservations on this point apply most clearly to our knowledge of God's purposes, or "those matters which depend upon the free will of God" (AT VII, 153/CSM II, 109; cf. AT II, 55). Such topics are beyond the scope of natural reason and can be known only through revelation (AT V, 158). He extends this criticism to the presumption of thinking that the world was created for the sake of human beings (AT III, 431; AT V, 168), or "that God is a kind of superman [magnum aliquem hominem], who thinks up such-and-such a scheme, and tries to realize it by such-and-such a means. This is clearly unworthy of God" (AT V, 158/CSMK 141). Several texts suggest the more far-reaching claim that we are not in a position to suppose any agreement between our reason and God's (AT VII, 146), and that our mind is not "the measure of truth or reality", but only "the measure of those things we affirm or deny" (AT V, 274).

22. Les Passions de l'ame (hereafter: PA), art. 152 (AT XI, 445); cf. Meditationes, IV (AT VII, 56-7); Principia philosophiae, art. 37 (AT IX, 18-19). 
insofar as they are perceived as true or good. Assent to the former is an affirmation of an idea's truth; assent to the latter, a choice to pursue an object as good. On Descartes's account, the will is determined to assent, unless there is some uncertainty in the representation given to it, that is, unless the truth or goodness of the object of the representation is not fully apparent. Hence, he concludes, "if I always saw clearly what was true and good, I should never have to deliberate about the right judgment or choice" (AT VII, 58/CSM II, 40).

This explanation of the natural operation of the will plays a critical role in the argument of the Meditations. There Descartes employs sceptical doubts to weaken untutored beliefs about nature, replacing them with "clear and distinct perceptions" to which the will naturally and properly assents. In pursuit of certain knowledge, the meditator learns to withhold assent from any idea whose truth is not clearly and distinctly perceived. In this he uses his free will correctly. We have seen, however, that in practical contexts, those involving an agent's assent to objects as good or choiceworthy, Descartes appears to substitute a weaker standard for the correct use of the will. He claims that we may use our will correctly even if we are not certain that we are thereby choosing the best outcome, or the greatest good that could be brought about by our action. Virtue requires only that we forbear acting until we have examined things "as well as we morally can" (AT V, 83-4).

There are two ways we might try to reconcile what Descartes says in these texts. On the one hand, we might suppose that there are different standards of evidence for theoretical and practical reason: while certain knowledge of truth is an appropriate standard in the theoretical domain, its practical analogue, certain knowledge of goodness, is too much to ask for. Such a reading is consistent with what Descartes says at the beginning of the Meditations, but it does not square with views he expresses elsewhere. On the contrary, he argues that in both theoretical and practical matters some certainty is possible; yet very often certainty is not available to us and still we must judge. ${ }^{23}$ In such cases, we must settle for moral certainty ("une certitude morale"), glossed in the French version of Principia philosophiae, as a certainty "suffisante pour regler nos moeurs, ou aussi grande que celle des choses dont nous n'avons point coustume de douter touchant la conduite de la vie, bien que nous sçachions qu'il se peut faire, absolument parlant, qu'elles

23. As he acknowledges at the end of the Sixth Meditation: "But since the pressure of things to be done does not always allow us to stop and make a meticulous check, it must be admitted that in this human life we are often liable to make mistakes about particular things, and we must acknowledge the weakness of our nature" (AT VII, 90/CSM II, 62; cf. AT VII, 350-1/CSM II, 243). The mistakes we make about resparticulares can involve judgments about their factual properties or about their value to us. 
soient fausses" (art. 205; AT IXB, 323). Here Descartes draws on the Academic doctrine, argued against the Stoics, that assent is justified on the basis of a weaker criterion than clear and distinct (or "kataleptic") perception. With respect to the conduct of life, including judgments about the truth and falsity of factual propositions, we are justified in assenting to what seems true (verisimilis), or is persuasive (probabile), provided we have examined the matter thoroughly. ${ }^{24}$

Descartes does not claim that we have only probable opinions in regard to matters of conduct. In fact, he believes that we can acquire some knowledge of good and evil, and of the requirements of action, that is as certain as metaphysical knowledge. Although he denies that virtue requires the perfection of our cognitive powers, because "la connoissance est souvent au delà de nos forces" (AT V, 83), he assigns to reason the role of evaluating the relative goodness of objects, so that we may assent to those which are most choiceworthy: "le vray office de la raison est d'examiner la juste valeur de tous les biens dont l'acquisition semble dependre en quelque façon de nostre conduite, affin que nous ne manquions jamais d'employer tous nos soins a tascher de nous procurer ceux qui sont, en effect, les plus desirables" (AT IV, 284). Furthermore, he argues that reason fulfills this role on the basis of its knowledge of those truths "qui sont le plus à nostre usage" (AT IV, 291). Summarizing these truths for Elisabeth, he says that they include, first, that there is an infinitely perfect God on whom all things depend and whose perfection is "le vray objet de l'amour"; second, that the noblest part of us is the soul, which is capable of existing without the body; third, that we are but a small part of a vast universe that does not exist for our sake alone (AT IV, 2912); and, fourth, that although each of us is a separate person whose interests are distinct from those of the rest of the world, the interests of the wholes of which we are part take precedence over our own interest:

[...] on doit toutefois penser qu'on ne sçauroit subsister seul, \& qu'on est, en effect, l'une des parties de l'univers, \& plus particulierement encore l'une des parties de cete terre, l'une des parties de cet Estat, de cete societé, de cete famille, a laquelle on est joint par sa demeure, par son serment, par sa naissance. Et il faut tousjours preferer les interets du tout, dont on est partie, a ceux de sa personne en particulier; toutefois avec mesure \& discretion, car on auroit tort de s'exposer a un grand mal, pour procurer seulement un petit bien a ses parens ou a son pais. (AT IV, 293)

The preceding truths express how reason represents the relative goodness of the objects that most concern us. God is the greatest good and the most worthy object of our love; the perfection of the will is the supreme

24. Cf. Cicero, Academica II, 99-100 (LS 42I); Sextus Empiricus, Adversus mathematicos, VII, 166-75 (LS 69D). 
good of any human being; and the promotion of the interests of the wholes of which we are part is, other things being equal, a greater good that the promotion of our individual interest. These are judgments that a rational agent will naturally make about the world, with implications for the actions that should be done by him.

What Descartes establishes here, in effect, is a class of appropriate actions, or officia, in the Stoics's sense: actions that reason represents as being in accord with nature. Recognizing the supremacy of God, "nous apprend $\dot{a}$ recevoir en bonne part toutes les choses qui nous arrivent, comme nous estant expressement envoyées de Dieu" (AT IV, 291). Recognizing the perfection of the soul and its independence from the body, "nous empesche de craindre la mort, \& detache tellement nostre affection des choses du monde, que nous ne regardons qu'avec mepris tout ce qui est au pouvoir de la fortune" (AT IV, 292). Recognizing that one is a part of a larger community whose interests take precedence over one's own, "on prend plaisir à faire du bien a tout le monde, \& mesme on ne craint pas d'exposer sa vie pour le service d'autruy, lorsque l'occasion s'en presente" (AT IV, 293). In short, in knowing these truths one is disposed to act as a virtuous person does under the guidance of reason. And the model of virtue at which Descartes gestures is very much a Stoic one: assent to God's will; depreciation of goods of fortune; acknowledgment of duties that reflect one's relationships with other human beings.

The truths about value that Descartes articulates support broad directives for action. For the most part, however, they are too general to specify exactly what one should do in any particular circumstance. ${ }^{25}$ This is seen most strikingly in the requirement to prefer the interests of the whole to self-interest - "toutefois avec mesure \& discretion, car on auroit tort de s'exposer a un grand mal, pour procurer seulement un petit bien a ses parens ou a son pais" (AT IV, 293). So framed, the requirement does not tell us what it is to act "avec mesure \& discretion". On what grounds do we decide how much weight to give to our own interests relative to those of a given whole, or how the interests of different wholes (family, country, humanity, etc.) are to be weighed against one another?

Quizzed on this point by Elisabeth, Descartes initially appears to brush aside the concern. It is not, he says, a matter in which it is necessary to be

25. Descartes acknowledges this point: "Outre ces veritez, qui regardent en general toutes nos actions, il en faut aussy sçavoir plusieurs autres, qui se raportent plus particulierement a chascune d'elles". (AT IV, 294) These further truths concern the care to be taken in evaluating the reasons for action offered by the passions and local customs, both of which contribute to determining action in the absence of more specific guidance from reason itself. In these circumstances, as I suggest below, we are limited to acting on "les opinions qui nous paroissent les plus vraysemblables" (AT IV, 295). 
very exact; it is enough that each satisfies his conscience and considerable room can be left for individual inclination. Anticipating Adam Smith's invisible hand, he ventures that a combination of enlightened self-interest and an effective system of legal and social sanctions can compensate for the lack of a strong moral disposition on the part of the general populace. This response, however, is immediately followed by the statement of a central idea of his own morale:

Et, outre cela, comme c'est une chose plus haute \& plus glorieuse, de faire du bien aux autres hommes que de s'en procurer à soy mesme, aussi sont ce les plus grandes ames qui y ont le plus d'inclination, \& font de moins d'estat des biens qu'elles possedent. Il n'y a que les foibles \& basses qui s'estiment plus qu'elles ne doivent $[. .].($ AT IV, 317)

In the Passions, Descartes emphasizes that virtuous individuals, those to whom he attributes the trait of "générositê" or "magnanimitê" 26 , have a proper estimation of their own value, which they locate in the correct use of their free will ( $P A$, arts. 152, 154). To use one's will correctly, as a virtuous person does, is to have a firm disposition to judge in accordance with reason. Consequently, given reason's dictate to prefer the interests of the whole to one's self-interest, virtuous individuals willingly promote the wellbeing of others, even to their own detriment: "ils n'estiment rien de plus grand que de faire du bien aux autres hommes \& de mespriser son propre interest". ( $P A$, art. 156; AT XI, 447-8)

It is clear, then, that Descartes defends an objective standard of conduct: that of the virtuous person. Yet this does not settle the question of how such a person decides on a course of action in any particular circumstance. It is not Descartes's position, any more than it is that of the Stoics, that a virtuous person never prefers his own interest to the common interest. For the Stoics, appropriate action begins with the impulse to preserve one's own bodily constitution, and this remains an action that reason recommends to an agent, even if there are circumstances in which it is overridden by the requirement to risk one's life in defending one's country or in extreme cases to take one's own life. In this we find an explanation of the qualification Descartes adds to his statement of the duty to prefer the interests of the whole to one's own interest: “toutefois avec mesure \& discretion, car on auroit tort de s'exposer a un grand mal, pour procurer seulement un petit bien a ses parens ou a son pais" (AT IV, 293). It is appropriate to pursue one's own interests, particularly the well-being of the body and the development of one's faculties, and it is appropriate to do so even when, by not doing so, some relatively small good could be done for others. The problem 
is deciding when this is justified and when it is not. What competence is required for an agent to decide what "measure and discretion" require in any particular case?

For the Stoics, this competence is identified with the epistemic state of the virtuous person. The sage has a perfect knowledge of how to act in every instance and performs that action because he knows it is the action to be done in that circumstance (thus he acts "in agreement with nature"). Descartes, by contrast, claims that such knowledge is beyond us; we cannot know what providence requires of us. In judging whether to perform a particular action, we have at most what the Stoic regards as opinions. Still, though we act on the basis of opinion, our action does not for that reason fall short of virtue. Rather, Descartes argues that virtue does not require perfect knowledge about the required course of action. It is enough that one acts in the right manner, allowing reason to guide the will as far as it can:

Et bien que nous ne puissions avoir des demonstrations certaines de tout, nous devons neanmoins prendre parti, \& embrasser les opinions qui nous paroissent les plus vraysemblables, touchant toutes les choses qui vienent en usage, affin que, lorsqu'il est question d'agir, nous ne soyons jamais irresolus. Car il n'y a que la seule irresolution qui cause les regrets \& les repentirs. (AT IV, 295)

If we adhere to the resolution to examine a situation as well as we can, weighing the reasons for and against possible courses of action, then we have done everything within our power. At that point, it remains only to act decisively on the opinions that seem closest to the truth ("les plus vraysemblables"), avoiding the negative effects of irresolution. ${ }^{27}$

We have seen that Descartes believes that an agent who acts virtuously may nonetheless fail to bring about "tous les biens dont l'acquisition semble dependre en quelque façon de nostre conduite" (AT IV, 284). Care must be taken in interpreting this claim. It is not his view that because virtuous agents operate on the basis of "opinions" concerning, for example, the priority of appropriate actions, their actions might turn out to be morally wrong as judged from a position of greater knowledge. The formula for virtue - a firm will to act as reason recommends - defines right action; hence, it is impossible for a virtuous agent to err morally, provided he is guided by knowledge of the most important general truths about value. Instead, Descartes claims that an agent can act rightly, in a manner consistent with virtue, and still fail to realize the greatest aggregate good, where this includes bodily and external goods that depend upon fortune. If an agent acts rightly, then he has acted in a way conducive to the attainment 
of the supreme good: virtue. But the same action may fail to produce other goods that the agent expects to achieve through his action. This may occur, for example, if we attempt to perform appropriate actions under conditions of uncertainty that no thorough examination of the facts could remove. If, after consulting available weather reports, we set out on a smooth sea and subsequently are caught in a storm leading to the loss of life or cargo, we cannot be said to have acted wrongly, even though the outcome would have been better had we remained in port.

Such a description of the way in which the performance of appropriate actions - actions justified by reason - may have unfortunate outcomes finds a parallel in Stoic treatments of the topic. Much like Descartes, Seneca acknowledges that in many decisions about how to act - whether to plant, to set sail, to wage war, to marry - we lack an absolutely certain impression ("certissimam rerum comprehensionem") on which to base our decision to act. We know that certain sorts of actions should be done, but we do not know when or how they are best done. Since the outcomes of such actions are uncertain, we must be content to be guided by reason and not truth. We are compelled to follow things that seem true ("veri similia") rather than those that are true. ${ }^{28}$

The position Seneca describes comes close to Descartes's, including their common reliance on the standard of verisimilitude. This may suggest that Seneca is not representing the wise or virtuous person, as the Stoics conceive him, but merely the person who performs media officia, actions for which there is a "persuasive reason". Seneca, however, explicitly cites this as the approach of the wise person, who, having examined the possibilities of action to the best of his ability, acts decisively, though with the mental reservation, "if nothing intervenes to prevent it". For this reason, we say of the wise person that

everything succeeds for him, and nothing happens contrary to his opinion, since he mentally presumed that something could intervene to block his aims. Fools are confident that fortune is plighted to them; the Sage considers both parts of it. He knows the scope of error, the uncertainty of human affairs, the many obstacles to planning; suspending, he follows the doubtful and slippery fate of things, and weighs uncertain events with his certain plans. But the reservation without which he makes no plans and begins nothing, even here protects him. ${ }^{29}$

As Seneca describes him, the sage is not omniscient. He does not possess perfect knowledge of the causal order of nature, so that he knows with

28. Seneca, De beneficiis, IV, 33.

29. Ibid. IV, 34 (trans. in Brennan 2000, p. 152-3). The following paragraph is informed by the discussion of Stoic reservation in Brennan 2000. 
certainty that the appropriate actions he performs will have their expected outcomes (e.g. delivering a benefit to a deserving recipient). What distinguishes the sage from the fool is that while the fool desires that an action will have its expected outcome, which he identifies with the success of the action, and is saddened if this does not happen, the sage has no such desire or sadness. He does not assent to the outcome but to the action, which he understands will have an anticipated effect "if nothing intervenes to prevent it" ${ }^{30}$ In this way, the sage insulates himself from the uncertainty of fortune and the possibility of error: he does not act on the belief that suchand-such an outcome should occur (as something desirable in itself), but that it will occur if this is consistent with God's will. If the outcome in question does not occur, then the sage has not erred (because he did not believe that that outcome would or should occur) and he has lost nothing good (because nothing but virtuous action is good). It is with this attitude that he possesses a will firmed by "right reason".

Seneca's depiction of the mental outlook of the sage lines up neatly with Descartes's position, down to the emphasis laid on the lack of remorse or regret in the person who acts decisively, assured that he has done everything within his power. The remaining gap between their views lies less in their treatments of appropriate action and virtue (though there remain differences in their accounts of the relation between divine and human reason and of the cognitive and conative powers of a rational soul), as in their conceptions of the good. Rejecting the Stoics's restriction of the good to the morally good (virtue or kalon/honestas), Descartes maintains that there are other naturally good things that an agent may desire (life, health, pleasure) and that he will be saddened if he fails to acquire such goods. ${ }^{31}$ Because Descartes holds that virtue is the supreme good, which is sufficient for happiness, he does not believe that we need suffer inordinately if we fail to attain these other goods; yet we will have lost something good, which we might have acquired if our knowledge had been more comprehensive.

30. "They [the Stoics] say that the good man experiences nothing contrary to his desire or impulse or purpose on account of the fact that in all such cases he acts with reserve and encounters no obstacles which are unanticipated". (Stobaeus, 2.115 [LS 65W])

31. With that said, in PA, art. 144, Descartes comes close to upholding the Stoic position: "Mais pource que la plus part de nos Desirs s'estendent à des choses qui ne dependent pas toutes de nous, ny toutes d'autruy, nous devons exactement distinguer en elles ce qui ne depend que de nous, affin de n'estendre nostre Desir qu'à cela seul. Et pour le surplus [...], nous ne devons pas laisser de considerer les raisons qui le font plus ou moins esperer, affin qu'elles servent a regler nos actions". (AT XI, 439) That which depends only on us, to which our desires should be limited, is the correct use of our free will, which is to "follow virtue" (PA, art. 144; AT XI, 436-7). This means estimating the value and likelihood ("les raisons") of different courses of action, while acknowledging that the eventual outcome of our action lies outside our power, as determined by God's providence. 
Thus, while possessing the supreme good, a virtuous agent may nonetheless fail to obtain "tous les biens dont l'acquisition semble dependre en quelque façon de nostre conduite" (AT IV, 284)..$^{32}$

Consideration of an agent's desires for the good, and of affects associated with those desires, leads us directly to Descartes's account of the passions. Here, too, we find suggestive parallels with the Stoics's theory, along with some significant divergences. A closer examination of Descartes's account will allow us to assess the extent to which he preserves further elements of the Stoic doctrine of kathekonta.

\section{Passions and the Convenable}

Human passions - love, hate, hope, fear, grief - are widely thought to impair the exercise of rational agency. When we act from passion, we may act in ways that do not reflect our core identity as agents, but the effects of external influences on us. In the worst case, we act as "slaves" of our passions rather than masters of ourselves. Remedies for this condition typically take one of two forms. A moderate position accepts that the passions play an important role in guiding our conduct, motivating us to pursue beneficial objects and avoid harmful ones, particularly as regards the safety and health of the body, but also in our relationships with other human beings. According to such accounts, the passions need only to be restrained so that they are not given undue influence over action and reason is able to exercise its authority. A more extreme position goes beyond this, arguing that there is something inherently wrong about the direction given to us by the passions, because they involve our ascribing goodness to objects that do not have such value. Given the Stoics's doctrine that virtue is the only good, they conclude that the sage will be without passion (apathe), understanding passions as impulses contrary to reason or false judgments about the goodness of anything other than virtue. ${ }^{33}$

The Stoics's notion of apatheia can easily lead to misunderstandings of their view. The elimination of passion in the sense they recommend does

32. Framed in this way, Descartes's ethics is reminiscent of the position of Antiochus of Ascalon, as discussed in book V of Cicero's De finibus (see especially De fin., V, 71-72, 95).

33. "They [the Stoics] say that passion is impulse which is excessive and disobedient to the dictates of reason, or a movement of soul which is irrational and contrary to nature; and that all passions belong to the soul's commanding-faculty [hegemonikon]" (Stobaeus, 2.88 [LS 65A]). Implicit in this description is the idea that a passion has both cognitive and conative aspects: it is a false judgment, or opinion, that something is to be pursued as good (or avoided as bad), and an impulse (horme) toward (or away from) that thing so represented. 
not mean the elimination of all non-rational motivation or feeling. ${ }^{34}$ The crux of the Stoic doctrine concerns the duty of agents to evaluate the objects toward which they are moved and to assent to (or withhold assent from) an object on the basis of a correct assessment of its value. In practice, we fail in our duty if we misjudge the proper grounds for our assent, ascribing goodness to something like health or survival that lacks such value. However, it does not follow that we are not naturally moved to pursue health or survival, or that we do not have reason to pursue these as ends. For the Stoics we do, provided we understand them as things to be selected rather than chosen, things that are "preferred" but not good. Judging in a manner that honors this distinction is the basis of the sage's claim to be apathe. A person whose reason operates as it should is not moved by passion, an impulse involving a false opinion about the goodness or badness of an object, but he may be moved by an impulse involving a true judgment that the same object is preferred or dispreferred. For the Stoics, actions of the latter sort, concerning things that are "according to nature", are kathekonta, or appropriate actions. ${ }^{35}$

Descartes defends a more measured view of the passions. ${ }^{36}$ At no point does he identify wisdom with the condition of being apathe. On the contrary, he says, the passions are "toutes bonnes de leur nature, \& $[. .$.$] nous$ n'avons rien à eviter que leurs mauvais usages ou leurs exces" ( $P A$, art. 212; AT XI, 485-6). This difference can be traced again to the broad extension he gives to the term "good", allowing it to range over natural goods as well as virtue. Because he does not question the claim of health or pleasure to be goods, albeit lesser goods than virtue, he finds no grounds for rejecting passions that motivate us to pursue such goods. This disagreement with the Stoics, though, is balanced by a deeper level of agreement. As Descartes defines the passions, they are impulses toward or away from objects represented as beneficial or harmful to the constitution of the body. Accordingly, Descartes's passions play a role analogous to the Stoics's appropriate impulses toward preferred things, or things according to nature. The two positions do not line up perfectly, because for Descartes the passions themselves are not judgments; nevertheless, the passions dispose the will to make judgments about appropriate action in a manner reminiscent of the Stoics.

34. Cf. the later Stoic doctrine of "propassions", as described in Aulus Gellius, Noctes Atticae, 19.1, 17-20 (citing a fragment of Epictetus) (LS 65Y), and Seneca, De ira, 2.3 (LS $65 \mathrm{X})$.

35. Cicero, De finibus, III, 22; ibid. 59.

36. There is a large and growing literature on Descartes's theory of the passions to which I cannot do justice here. Important recent contributions include: Kambouchner 1995; James 1997; Brown 2006; Perler 2011. 
Descartes famously writes that his intention in Les Passions de l'âme, " $n$ 'a pas esté d'expliquer les Passions en Orateur, ny mesme en Philosophe moral, mais seulement en Physicien" (AT XI, 326). His main point in describing his project in this way is to emphasize his novel explanation of the causation of the passions. Central to his account is that these mental states originate as changes in the physical state of the body, specifically different motions of the animal spirits, which are subsequently transmitted to the soul, where they are experienced as passions. According to his definition, passions in general are, "Desperceptions, ou des sentimens, ou des émotions de l'ame, qu'on raporte particulierement à elle, et qui sont causées, entretenuës et fortifiées par quelque mouvement des esprits" (PA, art. 27; AT XI, 349). This is another major departure from the Stoic doctrine, with significant consequences for how the passsions are to be managed. The Stoics deny that the passions originate in a separate part of the soul that has the power to resist the judgments of reason. Passions are aberrant impulses of the hegemonikon itself; hence, the rectification of those impulses through knowledge entails the elimination of the passions. Descartes, by contrast, concedes the power of the passions to resist correct judgments of reason, while also denying that they originate in a separate part of the soul. The challenge to rational agency posed by the passions is attributed to the fact that they originate outside the soul in the body. This means that the passions cannot be directly controlled by cognitive means. They make their influence felt on the will, which can resist them with correct judgments but cannot eliminate them entirely ( $P A$, arts. 46-47). Again, though, because Descartes regards the passions as "toutes bonnes de leur nature", he sees no need for this; at most it is necessary to curb their misuse or excesses.

Although only creatures with immaterial souls are the subjects of passions in the strict sense, the physical motions that produce the passions have a common physiological function in human beings and in brute animals. In both, the primary function of the agitation of the spirits that causes a passion is to dispose the body to respond to its environment in ways that promote its survival and health. Thus, underlying Descartes's account is a critical assumption about the teleological functioning of animal bodies, even purely mechanical ones. In its interactions with its environment, an animal registers influences that are harmful or beneficial to its body, and these physiological signals automatically produce movements adapted to the stimulus ( $P A$, art. 52). Although I won't expand on this point, the teleology of animal motion plays a prominent role in Descartes's text and brings to light a first sense in which the notion of appropriate action retains a place in his theory of the passions. Movements determined in this way by internal motions of the animal spirits are, in us and non-rational animals, movements directed toward the preservation and health of the 
body. Hence they are, to this extent, kathekonta: instances of "activity appropriate to constitutions that accord with nature". ${ }^{37}$

This physical account of proper functioning in animals forms the basis of Descartes's explanation of the passions in human beings. In our case, the motions of the animal spirits produce not just an autonomic response on the part of the body, but also a characteristic affective response in the soul: "une émotion" ( $P A$, art. 79), "une agitation" ( $P A$, art. 86), "une agreable émotion" ( $P A$, art. 91), or "une langueur desagreable" ( $P A$, art. 92). And this affective state, in turn, disposes the soul to will the things that nature deems useful to us and to persist in that volition ( $P A$, art. 52). Thus, we are naturally motivated to pursue, or avoid, things insofar as they are beneficial or harmful to the body ( $P A$, art. 137).

So far, Descartes's theory of the passions may seem to have little connection to the Stoics's. In particular, it is not clear what cognitive element, if any, is associated with the passions; how judgment is involved in the determination of action motivated by the passions; and how reason can correct errors of judgment to which we are led by passion. If the passions were merely affects that moved the soul as a consequence of prior physical causes, then even if they generally led to beneficial consequences for the body, there would be no opportunity for reason to exercise its control over them. For Descartes, however, the passions that serve as motives for the will are not merely effects of physical causes; they occur in conjunction with the representation of an object at which the passion is directed. This association between the occurrence of a passion, understood as an affective response in the soul to some physical stimulus, and the representation of an object at which the passion is directed, figures prominently in Descartes's definitions of what he takes to be the six basic types of passions:

L'Admiration est une subite surprise de l'ame, qui fait qu'elle se porte à considerer avec attention les objects qui luy semblent rares \& extraordinaires. ( $P A$, art. 70; AT XI, 380)

L'Amour est une emotion de l'ame, causée par le mouvement des esprits, qui l'incite à se joindre de volonté aux objets qui paroissent luy estre convenables. ( $P A$, art. 79; AT XI, 387)

Et la Haine est une emotion, causée par les esprits, qui incite l'ame à vouloir estre separée des objets qui se presentent à elle comme nuisibles. (ibid.)

La passion du Desir est une agitation de l'ame, causée par les esprits, qui la dispose à vouloir pour l'avenir les choses qu'elle se represente estre convenables. Ainsi on ne desire pas seulement la presence du bien absent, mais

37. DL VII, 108 (LS 59C). 
aussi la conservation du present; $\&$ de plus l'absence du mal, tant de celuy qu'on a deja, que de celuy qu'on croit pouvoir recevoir au temps à venir. (PA, art. 86; AT XI, 392)

La Joye est une agreable emotion de l'ame, en laquelle consiste la jouïssance qu'elle a du bien, que les impressions du cerveau luy representent comme sien. (PA, art. 91; AT XI, 396)

La Tristesse est une langueur desagreable, en laquelle consiste l'incommodité que l'ame reçoit du mal, ou du defaut, que les impressions du cerveau luy representent comme luy apartenant. ( $P A$, art. 92; AT XI, 397)

I pass over the passion of wonder ("l'admiration"), which Descartes defines as a sudden surprise in the soul that prompts it to consider attentively an object that seems to it "rare and extraordinary". In the case of the other five types of passion, the definitions involve explicit reference to the representation of an object as beneficial ("convenable", "bon") or harmful ("nuisible", "mal") to an agent. Descartes affirms the equivalence of these pairs of terms: for a thing to be represented as good with respect to us ("bonne à notre égard") is for it to be represented as appropriate to us ("nous étant convenable”) ( $P A$, art. 56; AT XI, 374). Thus, with the exception of wonder, all the passions are affective responses to the perception of an object as suitable or harmful to an agent, that is, as something with positive or negative value for him.

Descartes's classification of the passions differs from the Stoics's. Notable is his restriction of joy and sadness to affective states that involve an individual's enjoyment of, or distress at, something perceived as good or bad and as belonging to him. There is no reference to the will's assent to the goodness or badness of the object. The passion is merely an emotional response to what is perceived as good or bad for the agent. ${ }^{38}$ Descartes's descriptions of the passions of love, hate and desire line up more closely with the Stoics's canonical division of the passions into four basic kinds: lust (epithymia, libido) (= assent to a future object as good); fear (phobos, metus/formido) (= assent to a future object as bad); distress (lupe, aegritudo) (assent to a present object as bad); pleasure or delight (bedone, laetitia) (assent to a present object as good). ${ }^{39}$ For Descartes, desire incorporates the Stoics's distinction between appetite and fear. Desire is an agitation of the soul that disposes it to will for the future the presence of good or suitable things or the absence of bad or harmful things. Love and hate are emotions that move the soul to join itself volitionally to a present object that is represented as suitable to it (love), or to separate itself from a present object that is represented as harmful to it (hate). In the case of these three

38. $P A$, art. 94 (AT XI, 398-9).

39. Stobaeus, II, 88, 8-21 (LS 65A); Cicero, De fin. III, 35; Tusc. Disp. IV, 8. 
passions, Descartes's general claim about their role is upheld: they "disposent l'ame à vouloir les choses que la nature dicte nous estre utiles, \& à persister en cette volontê" ( $P A$, art. 52; AT XI, 372).

Commentators have disagreed on whether Descartes regards the passions principally as conative states or as states that have both conative (motivational) and cognitive (representational) aspects. In the case of desire, love and hate, his definitions favor the former answer: they are passions that "move" or "incite" the soul to an act of will in relation to an object represented as "convenable" or "nuisible". The passion itself is not identified with the representation of the object as good or bad. ${ }^{40}$ That role is assigned to sensory perceptions of pleasure and pain, which are not included in Descartes's list of the passions. He characterizes pleasure as an immediate representation of something as beneficial to the body (commodum, convenable), and pain, of something as harmful to the body (incommodum, nuisible). ${ }^{41}$ Although caused physically, the passions of desire, love and hate function psychologically as conative responses to these stimuli: they dispose the will to assent to the pursuit or avoidance (desire), or its unity with (love) or difference from (hate), an object represented as suitable or harmful. To the extent that passions dispose the will in this way, they impose a set of basic normative demands on agents. The representation of an object as suitable or harmful gives an agent a pro tanto reason to pursue or avoid that object (it is something of value or disvalue to him). The passion contributes the motive force of this reason: it moves the will to assent to the goodness or badness of the object. Noting Descartes's claim that the passions of desire, love and hate always occur in conjunction with the representation of an object as beneficial or harmful, we can in practice ignore the distinction between the cognitive and conative aspects of an agent's reason. Hence, we can say that a desire for $x$ entails, other things being equal, a reason to pursue $x$. Love for $x$ entails, other things being equal, a reason to affirm one's unity with $x$ and, if $x$ is another person, to acknowledge the demand that $x$ 's interests impose on one. ${ }^{42}$

40. For arguments supporting this conclusion, see Greenberg 2007; Brassfield 2012. Descartes himself is not scrupulous about this distinction, referring sometimes to a passion that "represents" the goodness or badness of an object: PA, art. 48 (AT XI, 367); art. 211 (AT XI, 487).

41. See Meditationes, VI (AT VII, 74; AT VII, 83 [Latin] and AT IX, 66 [French]).

42. Descartes assigns a critical role to love in supporting our sense of being related to others and of forming with them a whole of which we are a part. We are thus disposed to advance their interests, insofar as they are consistent with those of the whole, in preference to our own interest. The passion of love causes us to feel this in a particular way with respect to a limited number of individuals; however, Descartes also describes an emotion of intellectual love whereby we are moved to join ourselves willingly to those whom we judge to be "convenable" to us. A virtuous person, endowed with générosité, adopts this attitude with 
On Descartes's account, passions do not directly determine intentional action. They register as inclinations that prompt the will to assent to the represented object as good or bad, suitable or harmful. As we have seen, the will is a power of choice whereby we determine ourselves to act by assenting to things insofar as they are represented as good and rejecting them insofar as they are represented as bad. Descartes also credits the will with a power of withholding assent whenever the goodness or badness of an object is not represented in a clear and distinct manner by the intellect. Given this, we can infer the following about the role of the will in making judgments related to the passions. A passion that accompanies the representation of an object as harmful or beneficial presents the will with a reason to assent or reject the object as choiceworthy. However, the passion does not present the object in a way that the will is determined to assent or reject the object. The occurrence of the passion is consistent with the will withholding assent from the object, because countervailing reasons may count against the passionate representation of the object's value or the rightness of the course of action associated with it.

In deciding whether to assent to the object of a passion, it is essential to recognize that the harm or benefit represented in the passion specifically concerns the well-being of the body. That something is a bodily good is not by itself a reason to reject it. Such goods, and the joys they bring, form an important part of a happy life. Yet, by the same token, their being bodily goods means that one may have other reasons, associated with the pursuit of higher goods, for rejecting what one is passionately disposed to pursue. Consequently, it is the role of reason to evaluate whether the objects with respect to which we are moved by passions should be pursued or avoided:

[...] le vray usage de nostre raison pour la conduite de la vie ne consiste qu'a examiner \& considerer sans passion la valeur de toutes les perfections, tant du corps que de l'esprit, qui peuvent estre acquises par nostre conduite, affin qu'estant ordinairement obligez de nous priver de quelques unes, pour avoir les autres, nous choisissions tousjour les meilleures. (AT IV, 286-7)

Although the passions, in general, prompt the will to assent to things useful to the body, they are not to be relied on as guides to conduct. We have no reason to eliminate the passions, but we must be on guard against their misuse. This highlights the importance of the "strength of mind" that is integral to moral virtue. The weakest souls, Descartes writes, are ones in which the will "se laisse continuellement emporter aux passions presentes, 
lesquelles estant souvent contraires les unes aux autres, la tirent tour à tour à leur parti, \& l'employant à combatre contre elle mesme, mettent l'ame au plus déplorable estat qu'elle puisse estre". In such individuals, the will is continually opposed to itself, rendering the soul a slave of the passions $(P A$, art. 48; AT XI, 367). Thus, the will lacks "firmness" and "constancy", and its judgments are subject to error, being based on passionate representations that exaggerate the good or badness of things.

The strongest souls, by contrast, rule the passions rather than being ruled by them ( $P A$, arts. 211-212). Their "propres armes" in resisting the passions are not other passions, but "des jugemens fermes \& determinez touchant la connoissance du bien \& du mal, suivant lesquels elle [sc. la volonté] a resolu de conduire les actions de sa vie" (PA, art. 48; AT XI, 367). When such judgments have been formed, the will is able to respond in a firm and consistent way to whatever situation arises. Rather than being moved haphazardly by passion, the will operates from a considered plan of action. Ideally, these judgments are based on a true estimation of the value of things, for

[...] il y a pourtant grande différence entre les resolutions qui procedent de quelque fausse opinion, \& celles qui ne sont appuiées que sur la connoissance de la verité: d'autant que, si on suit ces dernieres, on est asseuré de n'en avoir jamais de regret, ni de repentir; au lieu qu'on en a tousjours d'avoir suivi les premieres, lors qu'on en decouvre l'erreur. ( $P A$, art. 49; AT $\mathrm{XI}, 368)$

What Descartes says about the passions is thus closely integrated with his account of virtue. A virtuous agent evaluates the harms and benefits represented in the passions and chooses or rejects them in relation to how they contribute to the best course of action. Acting in this way, he meets the demands of appropriate action with respect to the soul and the body, giving due weight to duties to God and other human beings, the correct use of his free will, and the enjoyment of bodily goods to the extent this can be done consistently with fulfilling the requirements of duty.

\section{Conclusion}

Although Descartes is not a Stoic, his moral philosophy incorporates several leading ideas of Stoicism: the identification of virtue with the perfection of the power of rational agency; the designation of virtue as our supreme good, which is sufficient for happiness; and, I have argued, the notion of kathekon, or "appropriate action", as the source of the normative demands recognized by rational agents. Descartes locates these demands both in the duties borne by human beings as rational agents and in actions 
whose aptness stems from their being "according to nature" in the sense that they promote the survival and health of the body.

Descartes describes the virtuous person as one who " $[n$ 'a] jamais manqué a faire toutes les choses qu'il a jugées estre les meilleures" ( $P A$, art. 148; AT XI, 442). He acknowledges that, in order to be virtuous, one must make every effort to ascertain the best course of action, fulfilling the duties one bears to God and to other human beings. If one possesses this knowledge and fails to act on it, allowing passion to rule, then one falls short of virtue. A person in whom this happens has a will that lacks "firmness" and "constancy". In principle, then, Descartes identifies the ideal of virtue with the character of the person who consistently and steadfastly performs the offices of a rational agent based on his knowledge of what is kathekon. To this extent, his position approaches that of the Stoics, albeit without embracing the theological implications of their formula of the end: "to live in agreement with nature".

We have seen, however, that Descartes extends the notion of virtue in ways that set him apart from the Stoics. By expanding the class of goods to include bodily and external goods, he accepts that one can act rightly (as duty requires) and still not act in the best manner, because one fails, through ignorance or misfortune, to acquire all the goods at which one's will aims. Such a scenario is inconceivable for the Stoics, who restrict the good to virtue and reject the possibility that one might use one's will as well as one can and still fall short of attaining everything on which one's happiness depends. ${ }^{43}$ For Descartes, if we "follow virtue", with a firm and constant will to do what reason recommends, we will get everything we need for happiness, but we may not get everything we want. If wisely managed, though, the uncertainty that accompanies the pursuit of goods other than virtue, and the disappointment that follows our failure to attain them, are not such as to threaten the core of our happiness. On this point Descartes marks his distance from Stoicism.

43. Cf. Cicero, expounding the Stoic view: "Yet a man who adopts the threefold division of goods inevitably lacks confidence. For how will he be able to be confident of bodily strength or secure fortune? Yet no one can be happy without a good which is secure, stable and lasting". (Tusc. Disp. V, 40 [LS 63L]) 


\section{BIBLIOGRAPHY}

ADAm, Ch. \& P. TANNERy (eds.) 1996: CEuvres de Descartes, 11 vol., Paris, 1996 (reprint of revised edition, Paris, 1969; original: Paris, L. Cerf, 1897-1909).

BRAssfield, S. 2012: "Never Let the Passions Be Your Guide: Descartes and the Role of the Passions", British Journal for the History of Philosophy, 20 (2012), 459-77.

Brennan, T. 2000: "Reservation in Stoic Ethics", Archiv für Geschichte der Philosophie, 82 (2000), 149-177.

BRown, D. J., 2006: Descartes and the Passionate Mind, Cambridge, 2006.

Cottingham, J., R. Stoothof and D. Murdoch (trans.) 1984: The Philosophical Writings of Descartes, 2 vol., Cambridge, 1984.

Cottingham, J., R. STOOTHOF, D. Murdoch, and A. Kenny (trans.) 1991: The Philosophical Writings of Descartes, vol. 3, The Correspondence, Cambridge, 1991.

GreenberG, S. 2007: "Descartes on the Passions: Function, Representation, and Motivation", Noûs, 41 (2007), 714-34.

InwoOD, B. \& L. P. GERSON, 1997: Hellenistic Philosophy: Introductory Readings, Indianapolis, $2^{\text {nd }}$ ed. 1997.

JamES, S. 1997: Passion and Action: The Emotions in Seventeenth-Century Philosophy, Oxford, 1997.

Kambouchner, D. 1995: L'Homme des Passions: Commentaires sur Descartes, 2 vol., Paris, 1995 (Bibliothèque du Collège international de philosophie).

- 2008: Descartes et la philosophie morale, Paris, 2008 (Hermann Philosophie).

LAGRÉE, J. 2004: "Constancy and Coherence", in S. Strange and J. Zupko (eds.), Stoicism: Traditions and Transformations, Cambridge, 2004, 148-76.

LONG, A. A. \& D. N. SEDLEY, 1987: The Hellenistic Philosophers, Volume 1, Translations of the principal sources with philosophical commentary; Volume 2, Greek and Latin texts with notes and bibliography, Cambridge, 1987.

MARSHALL, J. 1998: Descartes's Moral Theory, Ithaca, 1998.

MEHL, É. 1999, "Les méditations stoïciennes de Descartes: hypothèses sur l'influence du stoïcisme dans la constitution de la pensée cartésienne (1639-1637)", in P.-F. Moreau (ed.), Le Stö̈cisme au XVI et au XVII siècle, Paris, 1999, 251-80.

OlIVO, G. 1999: “'Une patience sans espérance'? Descartes et le stoïcisme”, in P.-F. Moreau (ed.), Le Stoïcisme au XVI' et au XVII siècle, Paris, 1999, 234-50.

PERler, D. 2011: Transformationen der Gefühle. Philosophische Emotionstheorien 12701670, Frankfurt, 2011.

Rodis-LeWIS, G. 1957: La Morale de Descartes, Paris, 1957 (Initiation philosophique, 27).

Rutherford, D. 2004: "On the Happy Life: Descartes vis-à-vis Seneca", in S. Strange and J. Zupko (eds.), Stoicism: Traditions and Transformations, Cambridge, 2004, 17797.

SHAPIRO, L. 2011: "Descartes on Human Nature and the Human Good", in C. Fraenkel, D. Perinetti, J. E. H. Smith (eds.), The Rationalists: Between Tradition and Innovation, Dordrecht, 2011, 13-26.

White, N. (trans.) 1983: Epictetus, The Handbook (The Encheiridion), Indianapolis, 1983. 